OPEN ACCESS

Approved by:

Frontiers Editorial Office, Frontiers

Media SA, Switzerland

*Correspondence:

Kenneth E. Okedu

hind.barghash@gutech.edu.om

Specialty section:

This article was submitted to

Smart Grids,

a section of the journal

Frontiers in Energy Research

Received: 06 May 2021

Accepted: 07 May 2021

Published: 26 May 2021

Citation:

Okedu KE and Barghash HFA (2021)

Corrigendum: Enhanced Dynamic

Behaviour of Grid Connected Wind

Farms in Load Participation and

Frequency Regulation.

Front. Energy Res. 9:705750.

doi: $10.3389 /$ fenrg.2021.705750

\section{Corrigendum: Enhanced Dynamic Behaviour of Grid Connected Wind Farms in Load Participation and Frequency Regulation}

\author{
Kenneth E. Okedu ${ }^{1,2,3 *}$ and Hind F. A. Barghash ${ }^{4}$ \\ ${ }^{1}$ Department of Electrical and Electronic Engineering, Kitami Institute of Technology, Kitami, Japan, ${ }^{2}$ Department of Electrical and \\ Communication Engineering, National University of Science and Technology, Muscat, Oman, ${ }^{3}$ Department of Electrical and \\ Electronic Engineering, Nisantasi University, Istanbul, Turkey, ${ }^{4}$ Department of Engineering, Germany University of Technology \\ (GUtech), Muscat, Oman
}

Keywords: grid frequency, wind energy, power grids, loads, renewable energy

\section{A Corrigendum on}

Enhanced Dynamic Behaviour of Grid Connected Wind Farms in Load Participation and Frequency Regulation

by Okedu, K. E. and Barghash, H. F. A. (2021). Front. Energy Res. 10:5750 doi: 10.3389/fenrg.2020. 606019

In the published article, there was an error regarding the affiliation(s) for Kenneth E. Okedu.

As well as having affiliation 1, they should also have "2 Department of Electrical and Communication Engineering, National University of Science and Technology, Muscat, Oman, 3 Department of Electrical and Electronic Engineering, Nisantasi University, Istanbul, Turkey."

The authors apologize for this error and state that this does not change the scientific conclusions of the article in any way. The original article has been updated.

Copyright (c) 2021 Okedu and Barghash. This is an open-access article distributed under the terms of the Creative Commons Attribution License (CC BY). The use, distribution or reproduction in other forums is permitted, provided the original author $(s)$ and the copyright owner(s) are credited and that the original publication in this journal is cited, in accordance with accepted academic practice. No use, distribution or reproduction is permitted which does not comply with these terms. 